\title{
Seven challenges for the study of urban movements
}

\author{
Oriol Nel.lo*
}

\begin{abstract}
The article explores the difficulties and opportunities derived from the study of contemporary urban movements through the discussion of seven questions: definition of urban movements; understanding of their social characteristics; assessment of the issues raised by the movements; continuities and novelties in their composition and behavior; political significance; relationship between urban movements and institutions; and the standpoint of the researcher.
\end{abstract}

Keywords: Urban movements, Urban policies, Social conflict

Madrid, Barcelona, Zaragoza, Santiago de Compostela, A Coruña, Cádiz... Since the spring of 2015 several of Spain's main cities have been governed by political forces separate from the traditional parties. This means that the upper echelons of the Spanish urban system, at the local level, are occupied by political leaders who assert their affiliation with urban social movements of varying significance. This is certainly the most visible expression of the growing importance of this type of movement in the last few years, particularly since the turning point of May 2011, when the largest Spanish cities were shaken by a wave of occupations of urban public spaces.

This situation is not exclusive to Spanish cities as it can also be found in other southern European countries: in a context of prolonged financial and social crisis, with institutions and parties discredited and apparently unable to redress the worsening living conditions of significant portions of the population, all types of civic initiatives have sprung up. While some of these are purely support groups or charities, others seek to organize groups of citizens to defend their rights or propose alternative forms of social and financial organization, and in some cases they also strive to win space inside institutions to further their objectives.

The spread of these movements has sparked a renewed desire to analyze and understand them. As we know,

\footnotetext{
*Correspondence: oriol.nello@uab.cat

Departament de Geografia, Universitat Autònoma de Barcelona, Barcelona, Spain
}

research into this subject has notable precedents, from the seminal work by Manuel Castells, The City and the Grassroots. A cross-cultural theory of urban social movements (1983), to the more recent study by David Harvey, Rebel Cities. From the Right to the city to the urban revolution (2013). The outstanding contributions from Catalonia include those of Alabart (1982), Huertas and Andreu (1996), Domingo and Bonet (1998) and Molinero and Ysàs (2010), as well as Marc Andreu's recently published doctoral thesis (2015). ${ }^{1}$

Analysis of the motivations, forms and effectiveness of the urban movements is particularly necessary in the present circumstances. These movements are often presented by institutions and the media as merely selfish expressions of a naysaying culture, or as alarming populist upsurges. In contrast, commentators with other standpoints frequently glorify them, endowing them with transformative capacities and programmes that they do not always possess. These simplistic and distorted visions obviously do nothing to improve our understanding-in fact they represent an intellectual and political barrier to any evaluation of these movements' real significance.

There is therefore a pressing need for a rigorous analysis of urban social movements but this task also throws down some formidable challenges. In part, these arise from the very nature of the social movements: their existence demands answers from researchers,

\footnotetext{
${ }^{1}$ For our part, we have examined this subject in Aqui, no! Els conflictes territorials a Catalunya (2003) and La ciudad en movimiento. Crisis social y respuesta ciudadana (2015).
}

Springer Open

(c) The Author(s) 2016. This article is distributed under the terms of the Creative Commons Attribution 4.0 International License (http://creativecommons.org/licenses/by/4.0/), which permits unrestricted use, distribution, and reproduction in any medium, provided you give appropriate credit to the original author(s) and the source, provide a link to the Creative Commons license, and indicate if changes were made. 
forcing them to take sides, in one way or another, and act accordingly. As we shall see, these challenges bring with them certain difficulties but, above all, they also open up substantial opportunities for both analysis and political practice.

\section{Defining urban movements}

The first challenge is undoubtedly that of defining the urban movements themselves. If a social movement constitutes an attempt to promote a common interest-from outside the sphere of established institutions-through collective action (Giddens), an urban social movement is one that not only takes the city as its stage but also as its motivation and subject. So, by standing up for public facilities and spaces, by defending the right to housing and mobility and by promoting services and practices based on the social economy, these movements take as their starting point the limitations and opportunities offered by the city and make a decisive contribution to the latter's configuration. Such social movements can therefore be considered authentic urban agents, instrumental in shaping the city.

Barcelona provides a good example of this trend (Nel-lo 2015b). Academics from the city have often been questioned by foreign colleagues about the movements' role in Barcelona's development. In general terms, Barcelona is often considered one the most well-off and beautiful cities in the world, as well as one of the freest and safest. For a long time Barcelona could even be posited as an example of how a city can radically transform its economy and built-up areas without losing social cohesion. Our colleagues then go on to ask: How come that, despite all this, the social movements have such a constant and sustained presence? Obviously, the way to answer this question is by turning round its premise: the city is what it is largely because of the impact of social movements. Without them, the Eixample would not be the Eixample we see today, nor would Nou Barris have its current levels of urbanization, and nor would much of the city's architectural and cultural heritage have been preserved.

However, defining urban movements is not without its complications. Firstly, any definition and demarcation of a city is in itself becoming an increasingly arduous task. If the integration of territory always makes it more difficult to clearly distinguish between city and country, urban and rural, is it really appropriate to talk about urban movements at all? How can we distinguish them from movements that defend natural resources or the landscape, which also have territorial origins and objectives? Secondly, we are now faced with a proliferation of social initiatives of vastly different sizes and significance. How do we separate those that are merely social practices from those that are movements? Do we have to apply criteria of continuity, in terms of time, scale or capacity to make an impact? In the present circumstances, is it not an exaggeration to speak of "movements of social innovation" when it comes to describing a proliferation of activities that are undoubtedly significant but till far from being articulated? These are not taxonomic niceties, as these problems of definition reflect the inherent difficulties of capturing the specificity of the phenomenon and evaluating its transformative capacities.

\section{Understanding the movements' social characteristics}

The second challenge facing us is understanding the interests and motivations embodied by the social movements. All too often, urban social movements have been explained, paradoxically, without taking into account their social characteristics. This evaluation clearly goes beyond simply identifying the possible class-based nature of these movements, in contrast with the standard practice of years gone by. The diversity of the movements and the complexity of our societies would make any simplistic approach to be futile. Nevertheless, any understanding of the nature of these movements presupposes an analysis of which citizens are most likely to take part in these expressions of collective action and what social interests motivate them.

Such an analysis can sometimes produce surprising results. For example, in the study Barrios y Crisis (which we undertook in the Universitat Autònoma de Barcelona along with the political scientist Ismael Blanco and other colleagues) we mapped out, on the one hand, the settings for social innovation activities in Catalonia and, on the other, the segregation patterns of social groups within the urban space. The superimposition of the two maps produces some revealing findings: the innovation activities are not predominantly found, as would be expected, in areas populated by the most disadvantaged citizens, or in those populated by the most prosperous, but in neighborhoods that present, despite the undoubted impact of the crisis, a more stable population and a greater tradition of organization (Blanco et al. 2015). Access to what could be termed social capital (Secchi 2013) seems to be very closely related to citizens' capacity to organize themselves to defend their social wellbeing and collective assets.

This single example is enough to demonstrate the importance of the social characteristics of the people making up urban movements in any analysis of the latter's strengths and limitations. In the Catalan case, the main methodological problem is the attainment of quantitative data that are sufficiently representative and 
sustained over time. The sources at our disposal with respect to territorial disputes (as in the Anuari Territori of the Societat Catalana de Ordenació del Territori), the population's propensity to join associations (as in the Panoràmic del Associacionisme, issued by the the "Torre Jussana" institution with respect to Barcelona) and social innovation (as in the Mapa de la innovació social of the Institut de Govern i Polítiques Públiques) are extremely interesting but incomplete in terms of both timescale and territory. $^{2}$

\section{Identifying the issues raised by the movements}

The third challenge is to identify the issues raised by today's urban movements. This involves, first of all, listening to what they have to say rather than what commentators and the media say that they say, or should say. Furthermore, it is also necessary to analyze what they do, which obviously does not always coincide with their own declarations about their objectives and demands. As we have already pointed out, these movements have largely emerged as a result of the social problems occasioned by the financial crisis and the policies that followed in its wake, as well as dissatisfaction and mistrust with respect to institutions and established forms of representation. It is therefore hardly surprising that the issues they raise are directly linked to these very same problems. These issues can be divided into three main categories.

Firstly, many of the movements seek to defend the city's collective patrimony, understood not just as its common goods (public spaces, resources, environmental quality) but also as its public assets (heritage, facilities) and citizens' rights (access to housing, social services). As we know, this patrimony is now being heavily squeezed in all southern European countries by the push towards privatization of common goods and reductions in public services (Mattei 2011). Secondly, urban movements bring to the table, with varying degrees of explicitness, the question of spatial justice: by standing up for the urban quality and services of each neighbourhood, they are demanding not only equitable access to income and services but also a comparable dignity for all the areas that constitute the city-a dignity that is now being increasingly called into question by rising social inequalities, urban segregation and

\footnotetext{
${ }^{2}$ Although obviously biased, another interesting source, relatively underused in academic circles, is the Anuario Estadístico del Ministerio del Interior. This contains data on the number of collective actions - demonstrations, sit-ins, etc.- in the public space, classified by province, with indications of their motivations and organizers. We have made a detailed examination of the problems involved in statistical understanding of Barcelona's urban movements in the article "Movimientos urbanos y defensa del patrimonio colectivo en la región metropolitana de Barcelona" (Nel-lo 2015b).
}

downscaling of public policies (Soja 2010). Finally, the movements bring to the fore the issue of democratic quality in the processes of decision-making and administration, in a global context characterized by growing doubts over the compatibility between capitalism and democracy (Streeck 2014).

As we can see, these issues are enormously important, and indeed crucial to the development of our societies, but formulating and resolving them is fraught with difficulties. Let us look at just a few of the most obvious problems. In cities that are becoming increasingly segregated, how can we define which communities have the right to decide on common goods and collective rights? Do the citizens of more prosperous municipalities have the right to enjoy "their" common goods, while those in poorer districts have to make do with "their" particular resources? Furthermore, as regards spatial justice, how do we proceed when this seems to come into conflict with social equity? For example, in Catalonia people dwelling in housing derived from unauthorized plot divisions in the 1960s and 1970s now often find themselves deprived of basic urban services. But endowing these sparsely urbanized and relatively underpopulated areas with an urban quality comparable to that of more consolidated urban areas would involve an extraordinarily high investment. In a situation characterized by scarcity of public resources, how can these circumstances be confronted without creating comparative grievances? Lastly, practices based on citizens' participation, often presented as an antidote to deficiencies in the democratic process, require citizens to be exceptionally well organized and mobilized: can a transformative programme of this kind be sustained in a general context of growing individualization and social fragmentation? Moreover, looking from the opposite viewpoint, is there not also a danger that criticism of the modus operandi of institutions and parties, however justified, might be turned into ammunition for interest groups who are really intent on reducing the weight of the public sector and undermining democratic guarantees?

\section{Distinguishing between continuities and innovations}

One of the dangers of studying today's urban movements is presenting as a novelty something that is in fact a reiteration of underlying trends and historical continuities. This question is particularly relevant in the case of Barcelona, which, as we have said, has a long tradition of citizens' movements, from the Bullangues to the Jamància revolts in the 19th century, from the Tragic Week of 1909 to the upheavals of the July 1936 Revolution, from the 1951 tram strike to the pro-democracy demonstrations in the final years of the Franco regime, from the occupations 
of public spaces in May 2011 to the mass demonstrations of recent years.

It seems undeniable, however, that some of the social actions of the last five years do present some innovative aspects (Subirats and García-Bernardos 2015). Besides the traditional activities of charities and social organizations, which is continuing and expanding, we can see the emergence of a growing number of initiatives of a different nature. Without abandoning efforts to alleviate the effects of the crisis on the populace, these aim to organize citizens to defend their own rights and come up with alternatives. Sometimes such initiatives manage to create what could be called spaces of social autonomy (the 80 self-governing premises in Barcelona's metropolitan region hosting a myriad of associations, the hundreds of consumers' cooperatives, the emerging field of alternative energy production): it is as if, in the face of the incapacity (or refusal) of the State and businesses to provide the necessary goods and services in accessible conditions, sectors of the population have decided to obtain them by their own means, with all the possibilities, risks and contradictions implicit in such an undertaking.

In contrast with trade unions, neighbourhood associations and traditional political parties, the urban movements have adopted new forms of organization (often created ad hoc for the occasion) that are less stable and permanent, more reticulated and horizontal. Other distinguishing features of the new forms of activism are the championing of assembly-based forms of organization and operation, the creative use of the social networks and repeated recourse to what Sidney Tarrow (1998) called disruptive forms of collective action. Moreover, the innovative use of social networks by the urban movements has become one of its main features. As international experience shows -from the sadly truncated Arab Springs to the occupations of squares in Athens and New York (Castells 2012) - the use of ICT by urban movements should not be considered as merely the adoption of new technological tools. On the contrary, it has proved instrumental in disseminating the objectives of the protests, building consensus, developing new forms of mobilization and promoting citizens' direct participation (Toret 2013; García-Galera et al. 2014).

The nature of the urban and territorial movements seems markedly different from that of the immediately preceding period. Whereas just over a decade agowhen we published Aquí, no! Els conflictes territorials a Catalunya (Nel-lo 2003)-we could say that such movements were largely reactive, now they have become more propositional; whereas they were primarily defensive, today they seem, to a large extent, to be on the offensive; whereas they were once local and single-issue, now they are complex and multidimensional; and, above all, whereas they used to be whimsically apolitical, many now defiantly proclaim their political identity. These trends are obviously neither linear nor homogeneous and can undoubtedly be subject to stagnation and reversals. The change in the nature of these movements can never be considered irreversible, but there is no doubt that we have witnessed a major turnaround.

\section{Grasping the movements' political significance}

The fifth challenge in the analysis of the urban social movements is therefore the problem of defining their political significance. As is well known, the indignation, fears, aspirations and hopes found at the roots of this type of collective action have given rise, over the last few decades in Europe, to very diverse political movements: from egalitarian to xenophobic, from internationalist to localist, from transformative to reactionary. When it comes to analyzing their significance, the main challenge, in our opinion, is to stay clear of the parameters normally used to describe traditional political parties-the very parties whose deficiencies have largely paved the way for the development of these movements.

In Catalonia, for example, it is customary to analyze the position of political forces and electoral trends in terms of a social axis (left/right) and a national one (Catalonian/Spanish) (see e.g. Colomer 2016). It is therefore very tempting to define urban movements along the same lines, but their complex nature is ill-suited to this type of simplification. On the one hand, regardless of how their participants identify themselves ideologically, the political significance of the urban movements cannot be separated from their social composition. Precisely because we are considering the significance of social movements, we must not forget that the political connotations of ideological positions vary according to which social subjects are holding these positions.

On the other hand, when it comes to defining urban movements politically, the patterns of left/right and Catalonian/Spanish can be enriched by considering other variables. Thus, as some political scientists have perspicaciously observed, understanding the position and motivations of these movements requires the addition of a third axis: the degree of the intensity and quality of democratic life. At one extreme, this axis would have values like participation, proximity, the joint formulation of policies and community work, with the other extreme represented by the delegation of decisions, centralized control, hierarchization and administrative professionalization. In a context in which the traditional vehicles of representation and governance-parties and institutions-are experiencing serious problems of credibility, the growth and acceptance of the social movements (in Catalonia, in Spain as a whole and in other European countries) can largely be explained by their position on this axis. 
The four classic quadrants of political life have proved insufficient to analyze the significance of today's urban movements. To fully grasp the full complexity of this significance, we must start by adding to axes $\mathrm{X}$ (social) and $\mathrm{Y}$ (national) an axis Z: democracy.

\section{Understanding the relationship with institutions}

Understanding the relationship between urban movements and institutions constitutes our sixth challengea challenge that a researcher often shares with the main players in the events. The people involved in the movements frequently see public institutions as foreign territory and adopt an antagonistic attitude towards them. Conversely, institutions usually see urban movements as a threat to their own programmes or, at best, an obstacle that has to be overcome. Academics and the media often not only share some of these crossed perceptions but also help to consolidate them.

A more subtle examination would suggest, however, that to fully achieve their objectives, urban movements must be able to bring their demands and aspirations to fruition by reconfiguring them as compulsory rulings. Therefore, no movement can spurn its relationship with the institutions: it has to attempt to exert an influence at an institutional level, to occupy spaces and, if it has an alternative project, to completely take over institutional government. Surely one of the most interesting aspects of the developments in recent years is the step that some urban movements have taken from considering the institutions as an enemy fortress to viewing them as an arena where stands can be taken, and even as a tool that can be used for transformative purposes (Blanco and Gomà 2016; Nel.lo 2015a).

This is a step that involves considerable risks, as demonstrated, for example, by the decline of the neighbourhood associations in Barcelona and so many other Catalonian cities after 1979. That year, with the return to democracy in Spanish local governments, some of their leaders went into the city councils, which in their turn took onboard some of the citizens' demands. The subsequent deterioration of urban movements was pronounced and lasting (Andreu 2015). In the current situation, the risk is again to renounce at being simultaneously part of the movement and part of the institution. It is not by chance that this is exactly what conservatives of all kinds are clamouring for: a choice between one or the other. Thus, citizens are told to choose between collective and institutional action, community leaders or elected representatives, self-management or public policies. Whereas in fact, the opportunity for transformation surely lies in a capacity to maintain and uphold a dual amphibious nature, to be at one and the same time both movement and institution.
Furthermore, the existence of urban movements can, in certain circumstances, significantly enhance institutional action that has transformative aims. The network of associations and social innovation initiatives that have emerged in recent years can be a powerful ally and effective collaborator in pushing ahead policies and running services. The joint formulation and implementation of policies between citizens' organizations and public administrations can improve the efficiency and democratic quality of administrative processes. Moreover, cooperation with community initiatives can reinforce institutions that have become circumscribed and weakened in administrative, economic and political terms. There are still considerable risks involved, however: on the one hand, cronyism can arise between institutions and citizens' groups; on the other, it is important to prevent the delegation of managing services to society from becoming an excuse for a progressive withdrawal of the public administrations. Following this path could lead, however paradoxically, to a place not far removed from the New Localism or Big Society advocated by the British Conservatives.

The relationships between the movements and institutions are thus replete with both opportunities and dangers. Prejudices and sectarianism constitute serious impediments for any creative approchement between the two camps. Dichotomic or manichean views of these two realities as opposed and watertight compartments lead more often than not to unproductive conclusions. Instead, we need to grasp the continuity between citizens' activities and the institutional sphere, between urban movements and city government, between society and politics.

\section{Acting accordingly}

The last of the challenges triggered by the study of urban movements has nothing to do with any methodological deficiencies or conceptual problems. Instead, it has to do the standpoint of the researcher. The urban movements are raising the major issues of our society. It has sometimes been asserted that they have neither the size nor the means sufficient to deal with such enormous questions (Castells 1983) but experience (and particularly the experience of Barcelona) shows that their actions can give rise to notable collective benefits. They are not, therefore, merely symptoms of discontent but also represent an effective instrument for changing the city and, maybe, planting the seeds of more wide-ranging social transformations.

Anybody who sets about studying these movements will inevitably feel touched and impressed by the action of thousands of men and women who, in a context of growing inequalities and risk of social division, are fighting 
to take their destiny in their own hands. This situation requires the researcher to take a stand and act accordingly. This is true as well for the urban planner. Urban movements not only take the city as a stage, but as we have said, raise crucial questions about its structure and functioning. Planners cannot possibly remain undaunted by the challenges posed by these movements and will inevitably be compelled to take sides. Responding to this demand for civic commitment is the ultimate challenge thrown down by any study of urban movements.

\section{Competing interests}

The author declares that he has no competing interests.

Received: 21 September 2016 Accepted: 25 October 2016

Published online: 02 November 2016

\section{References}

Andreu M (2015) Barris, veïns i democràcia. El movimient ciutadà en la reconstrucció de Barcelona (1968-1986), Barcelona, I'Avenç

Anna A (1982) Els barris de Barcelona i el moviment associatiu veïnal. Universitat de Barcelona, Barcelona

Blanco I, Brugué J, Jiménez E, Nel.lo O, Coords (2015) Barris i crisi. Barris desafavorits davant la crisis: segregació urbana, innovació social i capacidad cívica, Universitat Autònoma de Barcelona-Programa Recercaixa. https:// barrisicrisi.wordpress.com/

Blanco I, Gomà R (2016) El municipalisme del bé comú. Icària, Barcelona

Castells M (1983) The city and the grassroots. A cross-cultural theory of urban social movements, London
Castells M (2012) Networks of outrage and hope: social movements in the internet age. Polity Press, Cambridge

Colomer JM (2016) L'aventurada aposta per la independència, in Salvador GINER and Oriol HOMS, eds. Raó de Catalunya. La societat catalana en el segle XXI, Barcelona, Institut d'Estudis Catalans-Enciclopèdia Catalana

Domingo M, Bonet MR (1998) Barcelona i el moviments socials urbans. Mediterrània, Barcelona

García-Galera MC, Del Hoyo-Hurtado M, Fernández-Muñoz C (2014) Jóvenes comprometidos en la Red: el papel de las redes sociales en la participación social activa, in Comunicar XXII, 43

Harvey D (2013) Rebel Cities. From the right to the city to the urban revolution, London

Huertas JM, Andreu M (1996) Barcelona en lluita. El moviment urbà, 19651996, Federació d'Associacions de Veïns de Barcelona, Barcelona

Mattei U (2011) Beni comuni. Un manifesto, Laterza

Molinero C, Ysàs P (2010) Construint la ciutat democràtica. El moviment veïnal durant el tardofranquisme i la transició, Icaria

Nel.lo O (ed) (2003) Aquí, no!. Els conflictes territorials a Catalunya, Barcelona

Nel.lo O (2015) La ciudad en movimiento. Crisis social y respuesta ciudadana, Madrid, Díaz \& Pons

Nel.lo O (2015b) Movimientos urbanos y defensa del patrimonio colectivo en la región metropolitana de Barcelona, in Ciudad y territorio. Estudios territoriales, XLVII, p 184

Secchi B (2013) La città dei ricchi, la città dei poveri. Bari, Laterza

Soja E (2010) Seeking Spatial Justice, University of Minnesota Press

Streeck W (2014) Buying time: the delayed crisis of democratic capitalism. Verso, London

Subirats J, García-Bernardos A (eds) (2015) Innovación social y políticas urbanas en España. Experiencias significativas en las grandes ciudades, Barcelona

Tarrow S (1998); Power in Movement: Social Movements and Contentious Politics, Cambridge University Press

Toret J (2013); Tecnopolítica: la potencia de las multitudes conectadas. El sistema red 15M, un nuevo paradigma de la política distribuida, Barcelona, IN3 Working Paper Series

\section{Submit your manuscript to a SpringerOpen ${ }^{\circ}$ journal and benefit from:}

- Convenient online submission

- Rigorous peer review

- Immediate publication on acceptance

- Open access: articles freely available online

- High visibility within the field

- Retaining the copyright to your article

Submit your next manuscript at springeropen.com 